\title{
YouTube as a Media in English Language Teaching (ELT) Context: Teaching Procedure Text
}

\author{
Abdul Khaliq R. Nasution \\ Universitas Lancang Kuning, Pekanbaru. Indonesia \\ akrasyid04@gmail.com
}

\section{ARTICLE HISTORY}

Received :2019-06-13

Revised : 2019-07-01

Accepted : 2019-07-14

\section{KEYWORDS}

Media

YouTube

Video

Procedure text

\begin{abstract}
Media is one of the tools that can help the teacher in the teaching and learning process in a class, especially in EFL classrooms. There are two kinds of media, such as visual and audio. In this article, the writer wants to use video as media in the teaching-learning process, especially videos on YouTube. YouTube doesn't only have about fun videos, in YouTube can also use as learning media, in there we too can find so many education videos in every level, start from beginner, intermediate, and even for advanced level. In line with that, the writer wants to give a video about how to make or do something or the other word we can say it "procedure". The learning outcome is to make the students know about procedure text, especially in how to make and how to identify. Then, this article also wants to know YouTube is useful or not as learning media if we make it support us in teaching and learning process.
\end{abstract}

\section{Introduction}

Teaching using media can encourage students to take more responsibility for and control over their learning, engage in joint planning of the syllabus and take longer-term perspectives on their learning (Masterman , 1999). Since everybody knows that media give many advantages, teachers in their class should consider what media they are gonna give to the students in the teaching-learning process. Anderson (1976) classify media into ten types, such as Audio, Print, Audio Print, Proyeksi Visual Silent, Audio Visual Projection Silent, Visual Motion, Audio Visual Motion, Physical Object, Human and Environment and the last one is Computer. The use of all of those media is to deliver material to students in the class. In this article, the writer wants to use the YouTube application as his learning media in the teachinglearning process.

We can say YouTube is one of the effective media because inside there, we can find many videos that can support us while teaching in a class (Heriyanto 2018; Albantani, Madkur 2017; Almurashi 2016). Heriyanto (2018) assume that the finding in his article clearly show that YouTube offered statistically significant effects on the students' vocabulary acquisition. The findings of the study indicate that the participants positively viewed the use of YouTube in their lessons. The findings also exposed significant improvement in the students' vocabulary achievement. Also, Albantani, Madkur (2017) mention that The trends of 21 st-century learning that suggests the involvement of Information and Communication Technology (ICT) in educational actions can be realized by, among other ways, utilizing the social media in particular YouTube. In the field of Arabic language foreign teaching, YouTube provides a variety of learning sources that could be benefitted for enhancing the learners' Arabic language ability. Furthermore, the entertaining atmosphere because of the features of YouTube can also grow their learning motivation.

Then, Almurashi (2016) claims that the use of YouTube in teaching the English language plays a leading role in helping learners understand their English lessons. It can improve the performance of students and upgrade their levels in English courses. In other words, YouTube presented a substantial influence on students' understanding of English $\mathrm{He}$ also said that YouTube could be a good material to incorporate English lessons and it can help with understanding the lesson as well. It should be considered by English teachers in the classroom since many of the learners' responses in this study were positive. In short, the study showed that the YouTube website could be an effective method in dealing with students' difficulties and barriers to understanding English. In line with ideas above, (Alwehaibi, 2015; Watkin, Wilkins, 2011; Riswandi, 2016). Alwehaibi (2015) state that, it was recommended that YouTube should be considered as an effective instructional tool for enhancing content learning of EFL college students and as an important teaching resource in classrooms. In addition, Watkin, Wilkins (2011) also mention that using YouTube both inside or on the outside of the classroom can help students in their speaking, listening, and also pronunciation skills. 
YouTube videos can also be utilized as realia to stimulate cultural lessons, enhance exposure to World Englishes, and promote authentic vocabulary development. Even reading and writing activities can be structured around YouTube videos. In-class lessons and activities will be detailed, as will homework and projects requiring the use of online streaming videos. Then, Riswandi (2016) assume that the use of videos in YouTube can help students to improve their speaking skills and also can give them the motivation to learn more about English. The improvement is proven by student's speaking acquisition and also the score that they will gain.

The score of the speaking test has fulfilled the criteria for success. In addition, the students actively involved in learning activities and had high motivation toward the use of YouTube-based videos in the speaking class. The nature of the video, which provides picture and audio at the same time, can help the students train their pronunciation, enrich their vocabulary, and make them easier to find an idea in producing sentences while speaking.

The students can get information faster and feel more confident in dealing with the lesson as they not only depend on their speaking skills but also their comprehension. In addition, watching videos also unconsciously help the students learn grammar in an automatic way. The students got the input so well from the speakers, who are mostly native English, in YouTube-based videos. The more students watch the video also help them to easily practice their speaking, thus, it helps the student improve their fluency in speaking.

Therefore, based on the ideas above, the writer will use YouTube as learning media in EFL learners class because they want to make students more understand about procedure text. Thus, this study attempts to make some practical suggestions for EFL students to pay great attention to use YouTube as their learning media to have a good effect on their learning media that will improve their skill, not only in writing area but also in conversation, listening, and others that can help students understand about English.

\section{Method}

In the YouTube application, there are many kinds of videos that we can use while teaching inside in EFL classroom as learning media. It also served to learn videos for every skill in the English language. According to Carrier (1990), teachers must first adjust what video are taught in learning in the classroom so that it matches the level of language students have. The teachers also have to teach the language to their students. However, to teach them about language, the teachers should give media that will support them to improve their English, such as video on YouTube.
The teacher also chooses the appropriate video on the syllabus that is applied; the teacher can also use the time in the game for learning. The teacher must also be the correct learning model for his students, so students can be comfortable and participate in the class.

This means that the teacher can understand the video that they give to the students. Also, the writer wants to use a video about how to do or make something from YouTube application. The purpose is to want to know is it effective or not using video as learning media and is it can be motivation for students in their learning process.

\section{Result and Discussion}

\subsection{Cognitive reasons: audio-visuals}

Listening activities typically need all students to listen with the purpose to understand and then they require to answer questions that will test they comprehension based on the conversation on that audio, exactly the interaction or discussion is divided into two or more people. If video involving human speech in an interactive context is used in such cases, students can successfully interpret body language, or other non-verbal, paralinguistic information, which may aid their comprehension.

A study by Herron (1995) suggests that when a visual stimulus is used in the learning process of with spoken language, student comprehension scores in the study of English improved significantly. Such claims are also reinforced by Lake (2003) who cites Asher (1993) in saying that there must be an image attached to the mental representation of a word to retain and use it. Numerous other studies also support the use of video in language classrooms based on the importance of including non-verbal, paralinguistic components of communication to assist learners in their understanding and construction of meaning when conducting listening activities.

The literature on the use of video in the EFL classroom suggests that it may help students to visualize word meanings. For example, Iwasaki (2009) writes, "Visuals can help dramatize meaning" In keeping with this idea, Shrosbree (2008) provides us with a quote that underpins the notion for considering video over audio-only sources for listening activities: There is an obvious appeal to using video in the language classroom. Instead of the rather unnatural task of listening to a disembodied voice emanating from an audio player, learners can see the speaker and elements of the surrounding environment.

In line with that, even as native speakers, when we interact or converse with others, we usually see their faces. If we consider instances of interaction that are not face-to-face - such as in computer-mediated- 
communication - for both synchronous and asynchronous interactions, a huge range of emotion icons (i.e. emoticons) and other visual representations of paralinguistic cues are employed as a substitute for face-to-face contact, implying that paralinguistic (or body language) cues are an important part of communication (Joy, 2009). Additionally, the multisensory aspect of video may help reduce the cognitive demands on learners, where the more senses utilized when acquiring a new language, the easier this knowledge may enter our long-term memory (Swaffar \& Vlatten 1997).

In line that statements above, The cognitive support provided by video in language classrooms has been studied where some, such as Medina, find that it may help second language learners acquire vocabulary and grammar, improve spelling and develop the linguistic skills of reading, writing, speaking and listening" (2002, p. 1). Additionally, Weyers (1999) found that video-based instruction appears to improve students oral production and in particular, confidence in their speech. However, in contrast to these studies, Wagner (2007) has argued that it is unknown as to whether students learn from what they hear or from what they see. Wood (1999) also argues that video alone does not provide sufficient impetus for language learning, how-ever, when used with appropriate support material, can "activate the passive knowledge of language learners in particular, and assist with language assimilation and transfer, both in terms of that language presented as well as that which is implicitly suggested" (p. 95).

\subsection{Audiovisuals: multiple learning styles}

According to the VARK guide to learning styles a comprehensive guide to learning styles by Fleming (2001) - learners can be classified into either one or the other of the following four main learning styles or have two or more learning preferences (aka. multimodal):

a) Visual -process knowledge from maps, charts, spider diagrams etc.

b) Aural - prefer information that is spoken or heard.

c) Reading (or writing) - prefer to receive information via the written word.

d) Kinesthetic - process knowledge through bodily sensations (Gardner, 2006). The key point about kinesthetic learners is that they can learn from either real or simulated experiences, which can be interpreted as learning from movies, or other models of the foreign language in use.

Looking at the four learning styles, we can see that completing a listening activity via a CD (assuming aural only information) would be an appropriate source of input for the aural learners. However, using a video (aural and visual information) seems appealing to multiple learning styles: aural, visual and kinesthetic learners.

\subsection{Audiovisuals: affective reasons}

According to (Krashen, 1985), teachers must provide learners with not only an abundance of interesting, meaningful and relevant learning materials but additionally create a learning environment that helps to lower their affective filter. This links to theories of motivations, which suggest that learner motivation may be directly related to language acquisition, and the higher a learner's motivation is, the easier a language is acquired.

This paper argues that YouTube may provide suitable learning material to effect students' motivation and affective filter in a positive way. Among the results of a recent statistical analysis of YouTube, two statistics in particular help outline my argument and have implications regarding how YouTube may be exploited in the language classroom, according to Metekohy (2010):

- $70 \%$ of YouTube traffic comes from outside the US.

- Twenty-four hours of video is uploaded every minute.

The first statistic tells us that our students may very well be familiar with YouTube. If they are familiar with the medium, it may help lower the affective filter (Krashen 1982), and in turn, increase student motivation. Unlike a compulsory textbook, which students associate specifically with L2, they may associate YouTube with time spent having fun in their free time - a factor that may increase student motivation.

The second statistic shows that there is an abundance of material available from YouTube.com, some of which may be of use for pedagogical purposes. Although too much choice may make it hard to choose suitable teaching material, with inbuilt search facilities and related videos appearing on the same web page, YouTube can be navigated intuitively, and videos can be found with little difficulty. Therefore, YouTube may present language teach-ers with a useable medium for introducing language points, finding topics for discussion, or examples of authentic English, with proper guidance and suggested videos available on the site. Additionally, with 24 hours of new video being uploaded each minute, educators can use videos relating to news stories in real time as they unfold.

Attention should be taken when selecting videos for use with young or adolescent learn-ers due to the adult nature of some YouTube videos. Although registered users can only access videos with 
particularly strong adult themes, many videos may contain inappropriate language or themes with mild violence or sexual references. Some videos may also contain images or themes that are considered controversial or indecent to some cultures, so teachers should be careful when searching for videos on YouTube to use as appropriate teaching materials.

\subsection{Activities using YouTube}

The first way is to do a traditional dictogloss activity, with the use of video to aid student comprehension. Preparation for this activity requires the teacher to create a short narrative text based on the contents of a chosen YouTube video before the lesson is carried out in class. The lesson plan follows:

1) Preparation stage: The teacher explains each stage of the activity that class gonna do for that day and pre-pares the learners by introducing the topic and important vocabulary from the text. Students could also be asked to brainstorm vocabulary that they think may be relevant to the topic. But before that, the teachers must give ice breaking for warming up students in the class.

2) Dictation stage: The learners listen to a text read by the teacher at least two times. Standard procedure is for them to not write anything during the first listening to maximize potential comprehension and to get a feeling for the whole text. During the second listening, the learners take notes to help them reconstruct the text, and following the reading, they start to reconstruct the text individually. After that, the students is should make a procedure text based on the video that they had listened.

3) Reconstruction stage: Learners work together in small groups to reconstruct the text. And after that, 1 group presents their text in front of the class, and the others will give comments or suggestions. It is at this point where teachers may choose to show the video that the procedure text is based on. The reason being that at this point, students are undertaking the most demanding part of the activity meaning that motivation towards completing the task can start to decrease. Showing students a video of the text they have just heard is an excellent source of motivation as they can compare their stories to the visual, as well as their notes. The visual clues in the video can also be a good prompt to things they have missed out of their dictation.

4) Closing stage: In this stage, the teachers review the material that they give to students in the class, and ask students to conclude it. After that, the teacher gives the students give to them, or commonly we said it "task". Then the class is on end.

\section{Conclusion}

This article looked at several reasons for using YouTube in EFL classrooms with a focus on cognitive and affective reasons. Consideration was also given to students' different learning styles. While some studies have been inconclusive regarding the benefit of the video in the EFL context. I have assumed that video is useful in reducing cognitive load on learners and appeals to multiple learning styles. Affective reasons for the use of video was argued from the standpoint that there is a good possibility that is students are familiar with YouTube, which could have a positive influence on their motivation. Then, Based on every idea above, the writer wants to give proof that YouTube doesn't only hurt young learners. It can be great media while teaching, such as giving them motivation, reference to learning something and many more.

\section{References}

Albantani, A. M., \& Madkur, A. (2017). " Musyahadat Al Fidyu": YouTube-Based Teaching and Learning of Arabic as Foreign Language (AFL). Dinamika Ilmu, 17(2), 291-308.

Almurashi, W. A. (2016). The effective use of YouTube videos for teaching the English language in classrooms as supplementary material at Taibah University in Alula. International Journal of English Language and Linguistics Research, 4(3), 32-47.

Alwehaibi, H. O. (2015). The Impact of Using YouTube in EFL Classroom on Enhancing EFL Students' Content Learning. Journal of College Teaching \& Learning, 12(2), 121-126.

Ary, D., Jacobs, L. C., Irvine, C. K. S., \& Walker, D. (2018). Introduction to research in education. Cengage Learning.

Bärtl, M. (2018). YouTube channels, uploads and views: A statistical analysis of the past 10 years. Convergence, 24(1), 16-32.

Burgess, J., \& Green, J. (2018). YouTube: Online video and participatory culture. John Wiley \& Sons.

Hamuddin, B. (2016). Using blog to Promote English Skills for EFL Students: The Students' Perception. ELT-Lectura, 3(2).

Heriyanto, D. (2018). The Effectiveness of Using YouTube for Vocabulary Mastery. ETERNAL (English Teaching Journal), 6(1).

Herlinawati, H. (2014). Feedback in English Writing for Indonesian EFL Students. ELT-Lectura, 1(1). 
Herron, C. (1994). An investigation of the effectiveness of using an advance organizer to introduce video in the foreign language classroom. The Modern Language Journal, 78(2), 190-198.

Iwasaki, I. (2009). Edutainment for the EFL classroom: Exploring effective use of audiovisuals.

Jones, D., Bonwell, C., \& Fleming, N. (2001). vark: A guide to learning styles.

Lake, R. (2002). Enhancing acquisition through music. The Journal of the Imagination in Language Learning, 7.

Lusandi, B. (2018, May). Developing Maritime Thematic Expressions on English Reading Materials Used In Indonesia: Junior High School Context. In IOP Conference Series: Earth and Environmental Science (Vol. 156, No. 1, p. 012065). IOP Publishing.

Marwa, M., \& Herdi, H. (2017). Do Native Speakers in Youtube Videos Benefit EFL Students' Phonological Appropriation?. Lectura: Jurnal Pendidikan, 8(2).

Metekohy, M. (2010). YouTube statistics. Viral blog, 17 May.

Moghavvemi, S., Sulaiman, A., Jaafar, N. I., \& Kasem, N. (2018). Social media as a complementary learning tool for teaching and learning: The case of Youtube. The International Journal of Management Education, 16(1), 37-42.

Riswandi, D. (2016). Use of YouTube-based videos to improve students' speaking skill. In Proceeding of the International Conference on Teacher Training and Education (Vol. 2, No. 1, pp. 298306).

Shrosbree, M. (2008). Digital video in the language classroom. The JALT Call Journal, 4(1), 75-84.

Smith, D. K. (2014). iTube, YouTube, WeTube: Social media videos in chemistry education and outreach. Journal of Chemical Education, 91(10), 1594-1599.

Watkins, J., \& Wilkins, M. (2011). Using YouTube in the EFL classroom. Language Education in Asia, 2(1), 113-119.

Wekke, I. S., Yandra, A., \& Hamuddin, B. (2017, December). Learning Strategy in Class Management: A Reflection from Manado Case. In IOP Conference Series: Earth and Environmental Science (Vol. 97, No. 1, p. 012053). IOP Publishing.
Wright, D. G., \& Abell, C. H. (2011). Using YouTube to bridge the gap between baby boomers and millennials. Journal of Nursing Education, 50(5), 299-300.

Yasin, A., \& Syarif, H. (2014). Improving students'writing skill by using graphic organizer at the second year students English education department faculty of education and teachers training Lancang Kuning University Pekanbaru. English Language Teaching (ELT), 2(2). 